This item was submitted to Loughborough's Research Repository by the author.

Items in Figshare are protected by copyright, with all rights reserved, unless otherwise indicated.

\title{
Accountability to prevent corruption in construction projects
}

PLEASE CITE THE PUBLISHED VERSION

PUBLISHER

(C) ASCE

LICENCE

CC BY-NC-ND 4.0

\section{REPOSITORY RECORD}

Sohail, M., and Sue Cavill. 2019. "Accountability to Prevent Corruption in Construction Projects". figshare. https://hdl.handle.net/2134/3865. 
This item was submitted to Loughborough's Institutional Repository (https://dspace.lboro.ac.uk/) by the author and is made available under the following Creative Commons Licence conditions.

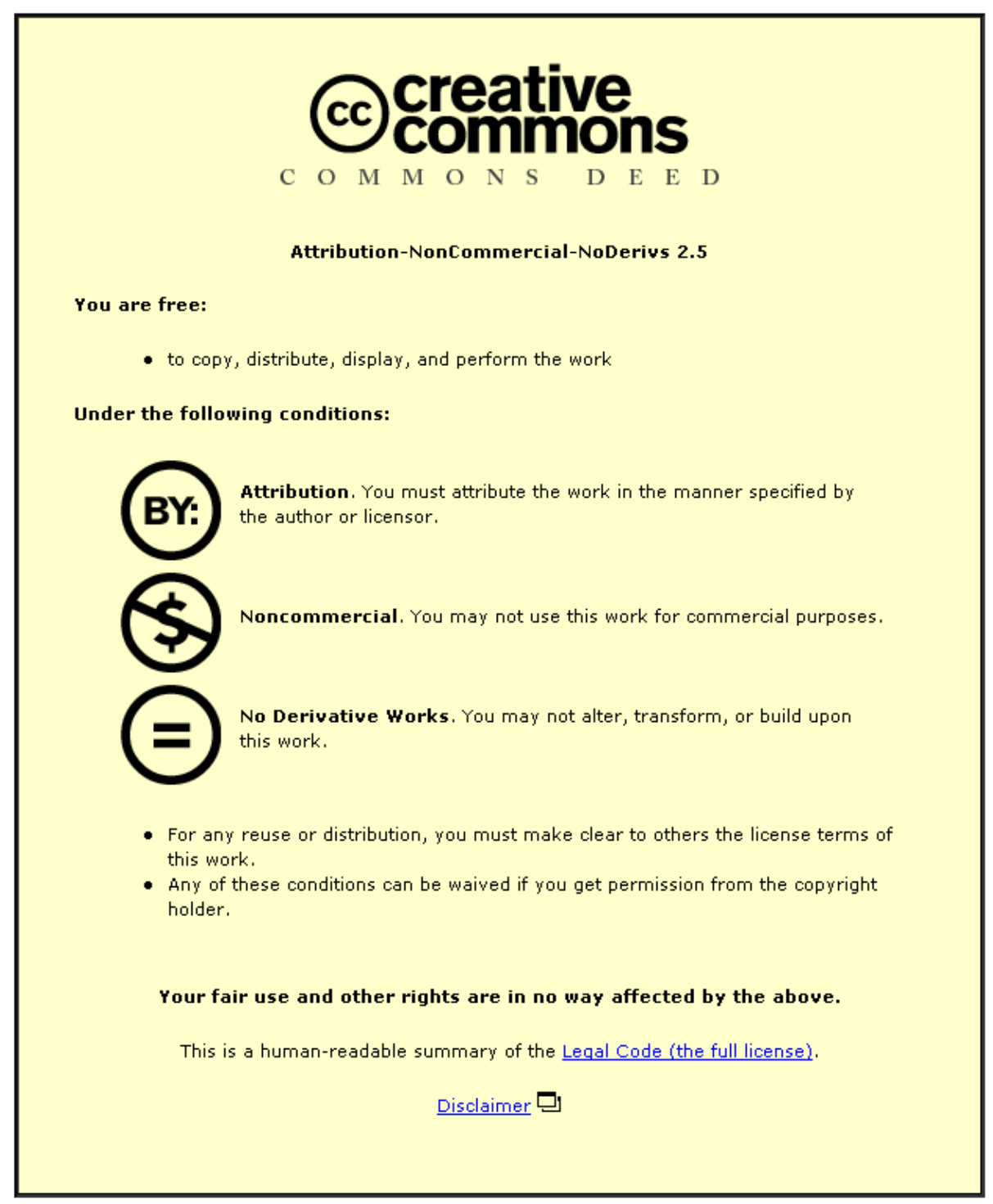

For the full text of this licence, please go to: http://creativecommons.org/licenses/by-nc-nd/2.5/ 


\begin{tabular}{|c|c|}
\hline Comment & Response \\
\hline \multicolumn{2}{|l|}{ Overall review } \\
\hline $\begin{array}{l}\text { The author draws conclusions about the effectiveness of accountability, } \\
\text { but has discussed four items within the framework before, not just limited } \\
\text { to accountability. The terms used here need to be tightened a bit and all } \\
\text { parts of the framework need full explanations in regard to the examples of } \\
\text { fighting corruption }\end{array}$ & Done \\
\hline $\begin{array}{l}\text { The conceptual framework stands as a quasi-methodology better for the } \\
\text { paper, then follow that methodology through analysis and finally with } \\
\text { appropriate findings. }\end{array}$ & Done \\
\hline $\begin{array}{l}\text { Possibly strengthen the paper by proposing an implementation plan for } \\
\text { the framework identified. The paper gave no indicators of actually } \\
\text { applying the methodology }\end{array}$ & Done \\
\hline \multicolumn{2}{|l|}{ Reviewer 1} \\
\hline $\begin{array}{l}\text { Page } 3,4,5-\text { rethink the word sustainable - is it physical environment or } \\
\text { environmental issues }\end{array}$ & $\begin{array}{l}\text { Sustainability } \\
\text { defined }\end{array}$ \\
\hline $\begin{array}{l}\text { Page 4: the second paragraph should also mention the section 'reviewing } \\
\text { the conceptual framework'. The framework is the best vehicle for bringing } \\
\text { all the various definitional and concepts within this paper to a central } \\
\text { message... Expand this section as a set of findings in the literature based } \\
\text { on the framework outlined earlier. A table might be good for organisation } \\
\text { here. }\end{array}$ & Done \\
\hline $\begin{array}{l}\text { Page 5-9- the conceptual framework seems more of a set of definitions } \\
\text { and concepts that you are laying out to later apply to industry practices. } \\
\text { This framework does not tie all of the definitions together, though, and this } \\
\text { alone reduces its effectiveness. Please allow a part of the paper to tie in } \\
\text { all of the different elements of this section (at the end of section) that can } \\
\text { then be used for 'reviewing the conceptual framework' later }\end{array}$ & Done \\
\hline $\begin{array}{l}\text { Page } 9 \text { first paragraph Table is an afterthought here. The table is } \\
\text { interested and well-established and should be discussed more in the text } \\
\text { and applied to the conceptual framework }\end{array}$ & Done \\
\hline $\begin{array}{l}\text { Page 9- beginning of the second full para. Please list these items instead } \\
\text { of making one long sentence }\end{array}$ & Done \\
\hline $\begin{array}{l}\text { Page } 10 \text { - end of the first para - please expand on the final sentence - the } \\
\text { forms of corruption that is individual to the construction industry is } \\
\text { important for your argument and should be explained in more than one } \\
\text { sentence. Consider offering a paragraph to each form of corruption }\end{array}$ & Done \\
\hline $\begin{array}{l}\text { Page } 11 \text { - first full para - this example of awareness raising seems less } \\
\text { construction industry specific. Please provide better examples specific to } \\
\text { the industry in this section }\end{array}$ & Done \\
\hline $\begin{array}{l}\text { Page } 12 \text { - second para this section seems to be more awareness than } \\
\text { prevention }\end{array}$ & $\begin{array}{l}\text { Integrity Pacts are } \\
\text { primarily aimed at } \\
\text { preventing } \\
\text { corruption }\end{array}$ \\
\hline $\begin{array}{l}\text { Page } 16 \text { - first full para this section seems more awareness than } \\
\text { enforcement }\end{array}$ & Para moved \\
\hline $\begin{array}{l}\text { Page } 16 \text { - last para - please expand more on this part as it is termed } \\
\text { critical }\end{array}$ & Done \\
\hline $\begin{array}{l}\text { Page } 17 \text { - second para - the author draws conclusions about the } \\
\text { effectives of accountability, but has discussed four items within the } \\
\text { framework before, not just limited to accountability. The terms used here } \\
\text { need to be tightened a bit and all parts of the framework need full } \\
\text { explanations in regard to the examples of fighting corruption. The previous } \\
\text { section titled corruption in infrastructure services and 'accountability } \\
\text { arrangements to reduce corruption' should reflect all the parts of the }\end{array}$ & Done \\
\hline
\end{tabular}




\begin{tabular}{|l|l|}
\hline framework, not just selections. & \\
\hline $\begin{array}{l}\text { Page 17: this section of the paper needs work to bring together the } \\
\text { framework and the discussed examples. This should be a findings section } \\
\text { that reinforces the methodology used and the analysis performed }\end{array}$ & Done \\
\hline $\begin{array}{l}\text { General note - the conceptual framework stands as a quasi-methodology } \\
\text { while the authors should define a methodology better for the paper, then } \\
\text { follow that methodology through analysis and finally with appropriate } \\
\text { findings. The lack of this methodology and process causes the paper to } \\
\text { meander a bit and not flow on certain points that are key to providing } \\
\text { valuable findings. This process needs to be defined and followed before } \\
\text { this paper can offer new knowledge on the subject }\end{array}$ & Done \\
\hline Reviewer 2 & $\begin{array}{l}\text { Possibly strengthen the paper by proposing an implementation plan for } \\
\text { the framework identified. The paper gives no indication of actually } \\
\text { applying the methodology }\end{array}$ \\
\hline $\begin{array}{l}\text { Page 6: first para - consider changing the word get in the last sentence to } \\
\text { gain }\end{array}$ & Done \\
\hline $\begin{array}{l}\text { Page 8: the last para change the word benefiting to benefit. Also the five } \\
\text { points listed in the section have no references associated with them. What } \\
\text { are these 5 based upon? Personal observations, literature or other } \\
\text { hypothesis? }\end{array}$ & Done \\
\hline Include a section that provides recommendations for future research & $\begin{array}{l}\text { Haven't included this } \\
\text { due to limited by } \\
\text { word count }\end{array}$ \\
\hline $\begin{array}{l}\text { The model needs to provide more evidence of how the recommendation } \\
\text { can work }\end{array}$ & Done \\
\hline
\end{tabular}




\section{Title Page}

\section{Title: Accountability to prevent corruption in construction projects}

Authors: M.Sohail (ASCE member) and S. Cavill

Corresponding Author: m.sohail@lboro.ac.uk Tel: +44 1509222 890. Fax +44 1509211079

Contact: Department of Civil and Building Engineering, WEDC Institute, Loughborough University, Ashby Road, Loughborough, LE11 3TU, UK.

Audience: Practitioners and researchers.

Specialty area: Organizational Issues.

Subject headings: Civil engineering, ethics, construction

Types of Submissions: Technical Papers

journal-submissions@asce.org 


\title{
Accountability to prevent corruption in construction projects
}

\author{
Abstract \\ The American Society of Civil Engineers claim that corruption accounts for an estimated \$340 billion of \\ worldwide construction costs each year. Corruption (including bribery, embezzlement, kickbacks and \\ fraud) in construction projects undermines the delivery of infrastructure services. Furthermore, corruption \\ poses significant risks to construction and engineering companies themselves. What progress has been \\ made, therefore, in reducing the risk of corruption to construction projects? It is the purpose of this paper to \\ argue that with improved accountability, attention to ethics and cultural considerations, and reduced \\ corruption, it is possible to construct, operate and maintain adequate quality and quantity of infrastructure \\ on a more sustainable basis and thereby improve construction practice. This paper will demonstrate how \\ accountability initiatives in construction projects, in developed and developing countries can be of benefit \\ internationally to the public and private sector as well as Non Government Organisations and researchers in \\ their efforts to reduce corruption in infrastructure services.
}

Keywords: civil engineering, corruption, ethics, construction

Word count: 6000 


\section{Introduction}

The construction industry has a world wide reputation for incidences of corruption, asset misappropriation and bribery. Transparency International’s Bribe Payers Index (2005) repeatedly reveals corruption to be greater in construction than in any other sector of the economy. The global construction market is worth around US \$3,200 billion per year. This market represents 5-7 per cent of GDP in developed countries and around 2-3 per cent of GDP in lower-income developing countries (Rodriguez, Waite \& Wolfe, 2005). However, the American Society of Civil Engineers (2004) claim that corruption accounts for an estimated $\$ 340$ billion of worldwide construction costs each year and the Institution of Civil Engineers (UK) estimates that corruption affects $5 \%$ of consultancy work. Nonetheless, there is a growing desire to eradicate corruption from the industry as demonstrated by the corruption-free execution of a massive set of investment projects associated with The Airport Core Programme in Hong Kong (total capital cost exceeded HK\$160 billion) (Rooke \& Wiehen, 1999) together with the aim of the Beijing Olympic Organising Committee to make the US\$16 billion construction project the most corruption-free Olympic construction project ever.

The paper is structured as follows: The purpose of Section 1 is to present a conceptual framework for this paper. The conceptual framework of this research consists of four components: ‘accountability', 'cultural norms', 'ethics' and 'corruption'. Section 2 moves on to examine how corruption affects the way infrastructure services are delivered in greater detail and gives examples of different types of corrupt practices which can take place between stakeholders during the various phases of a construction project. Understanding these corrupt interactions is critical to effective policy making in the construction sector. Section 3 will then set out the key aspects for the success of operationalising the four components: 'accountability', 'ethics', 'cultural norms' and 'corruption' in the context of infrastructure services; the common elements uniting all of these measures are awareness raising, strengthening professional institutions, prevention of corruption, and enforcement and monitoring measures. Finally, the paper reviews the links between accountability, norms, ethics, corruption and construction in practice. 
It is the purpose of this paper to argue that with improved accountability, attention to ethical and cultural considerations and reduced corruption, it is possible to construct, operate and maintain adequate quality and quantity of infrastructure on a more sustainable basis. This will, thereby, improve construction practice by ensuring 'capacity for continuance'. This paper is based on a literature review and the initial findings of an on-going research project undertaken by the authors on anti-corruption practices for infrastructure services in a number of countries in South Asia, Southern Africa, Central Eastern Europe and Latin America. It is intended that this paper will be of relevance to both industry practitioners and researchers.

\section{Conceptual framework}

This paper brings together a number of key concepts to develop a conceptual framework for analysing the issue of accountability in the context of construction. The conceptual framework for this paper is a relational model based on a set of four concepts 'corruption', 'cultural norms', 'ethics', and 'accountability'. These concepts are then linked to a system of functions and behaviours: the system consists of awareness raising, strengthening professional institutions, prevention of corruption, and enforcement and monitoring measures. The conceptual framework has been developed from the literature review and field research. The conceptual framework will be used to review the links between accountability, norms, ethics, corruption and construction in practice, and to draw conclusions about the effectiveness of accountability in combating corruption in the sector.

\section{Corruption}

A general definition of corruption is the misuse of power for private gain either at one's own instigation or in response to inducements. Corruption can be 'grand' (involving large amounts of money and taking place at the highest levels of society, and involving politicians, senior officials, political decision-makers, leading elites and major companies) or more commonly 'petty' (involving small amounts of money and which 
citizens may experience in their daily encounters with junior public officials such as policemen). Various forms of corruption include:

- Bribe - payments made in order to gain an advantage or to avoid a disadvantage,

- Fraud - theft through misrepresentation,

- Embezzlement - misappropriation of corporate or public funds,

- Kickbacks -sweeteners or rewards for favourable decisions.

Most commentators focus on those who abuse their public office for private gain; whereas the bribe payers are often given less attention and sometimes depicted as innocent parties. However, corruption can be 'collusive' (the willing and planned cooperation of the giver and taker), and 'anticipatory' (paying a bribe in anticipation of favourable actions or decisions from an authority) as well as 'extortionary' (forced extraction of bribes or other favours from vulnerable people by those in authority) (Davis, 2004). For instance, at least a dozen companies were found to have bribed the chief executive of the Lesotho Highlands Water Project (now serving a 12-year jail sentence for taking bribes), and the Lesotho courts have managed to gain convictions of a number of companies who were then debarred by the World Bank for their involvement in the scandal.

In the past commentators proposed that corruption might be an acceptable and normal means of obtaining routine low-level actions and/or approvals by officials. For example, Klitgaard (1988: 31) suggests that corruption can in fact benefit private actors by putting "goods and services in the hands of people who value them the most, who use them the most”. Thus, corruption may benefit people by cutting red tape by making decision-making predictable, motivating underpaid workers and enabling some to obtain political power e.g. selling a vote for services.

However, other observers claim that corruption is harmful and as such it has become increasingly unacceptable to a broad range of stakeholders, including businesses, governments, academics, and ordinary citizens (World Bank, 2004). It is argued that corruption is a significant barrier to economic, social and political development and poverty reduction. Other serious consequences of corruption include: 
- Lower economic growth rates (Robinson, 1998) for example The Commission for Africa (2005) identified corruption as the single most important explanatory factor for the lack of economic development in Africa.

- Ineffective government (Rose-Ackerman, 2004);

- Infringement of civil/political rights (Persson, Tabellini \& Trebbi, 2003);

- Decrease in investment of foreign and domestic investors (Alesina \& Weder, 2002);

- Lower quality of public infrastructure as the loss of revenue, diversion of public funds, and evasion of taxes associated with corruption mean that governments have less to spend on infrastructure (Bo Dal \& Rossi, 2004; DFID,2002);

- Reduced effectiveness of provision of public goods as sectors that do not lend themselves to grand corruption, such as social services, are given less emphasis than those which offer greater opportunities for corruption. (Deininger, 2003)

\section{Cultural norms}

Different cultures have varying degrees of tolerance for corruption. Gift giving is particularly common among business partners for example in Korea there is a set of practices called Chonji (which literally means money as a token of appreciation) and Kwan-Si (acquaintanceship culture) (Korea Centre for City and Environment Research, 1999), in China there is guanxi (social relationships or social connection), and in Russia there is a set of practices similar to those described above called blat (Andvig and Fjeldstad, 2000; 72).

Williams (1987) states how corruption is defined depends on the context in which it is located, the perspectives of the definers and their purpose in defining it. This means that different cultures have differing explanations of corruption, its causes, and how to respond to it; thus corruption is constructed differently across cultures and is not constant or predictable. Thus, according to such a view, corruption isn't good or bad objectively; rather may be tolerated in a society where it is "necessary" to conducting 
business, but disapproved in different setting for whatever social, historical and cultural reasons. Thus any mechanisms designed to combat corruption must be a grounded, culturally appropriate approach.

\section{Ethics}

The Transparency International Corruption Perceptions Index consistently points to corruption as an international problem, irrespective of culture. It can, therefore, be argued that corruption is not a cultural problem but an ethical one: for instance, no matter how pervasive bribery may be in some countries, no country openly defends the demand for, or the payment of, bribes as ethically acceptable. Thus, culture cannot be used to excuse unacceptable behaviours or poor ethical practice..

Ethics is the study of what we ought to do (actions and decisions) when faced with ethical dilemmas and how we do it, both as part of an organisation and as individuals. The Committee on Standards in Public life (the Nolan Committee) established the principles of ethical behaviour as: fair reward, integrity, honesty, objectivity, accountability, reliability, and fairness. Ethics issues facing construction sector include conflicts of interest, financial and accounting integrity, corruption and bribery, consumer and employee privacy, and ethical advertising. The public sector and companies are currently designing programs that give employees a level of ethical understanding that allows them to make appropriate decisions when faced with an incidence of corruption, rather than requiring compliance with organizational policy and procedures (written codes of business ethics and conduct) or external laws and regulations.

\section{Accountability}

The development of accountability is central to tackling corruption. Accountability works by formalising expectations of action or behaviour, creating sanctions for failure, enabling trust, and providing the motivation and incentives to use resources efficiently and effectively (Cavill \& Sohail, 2005). There are many different types of accountability and many different routes to achieve it. By way of general definition, Schedler, Diamond and Plattiner (1999; 17) state “A is accountable to B when A is obliged to 
inform B about A's (past or future) actions and decisions, to justify them, and to suffer punishment in the case of eventual misconduct”.

It is hypothesised that greater accountability can be of benefit in combating corruption in terms of:

1. Making service providers explain and justify their actions against commonly agreed standards of effectiveness, together with increased citizen monitoring, is intended to increase the probability of detection and promote transparency in interactions between public and private sectors.

2. Reducing the incidence of corruption - by reducing bureaucratic procedures, increasing service standards, clarifying responsibilities for regulatory, policy-making and delivery.

3. Reducing the kind of discretion in service delivery that may result in denying full service provision to certain people, or the selective provision of information.

4. Creating demand for better services by changing levels of tolerance for poor service leading citizens to reveal their demand for better quality and more accountable infrastructure services.

5. Creating sanctions for those found to have behaved immorally or performed ineffectively.

Thus, the different elements of this framework are corruption, cultural norms, ethics and accountability. It is hypothesised that any initiative to combat corruption through improved accountability will need to integrate both universal ethical principals as well as culture-bound attitudes and customs if it is to prove successful. This hypothesis will be re-examined later in the paper in the section 'Reviewing the Conceptual Framework' in light of the evidence presented in the following sections.

\section{Corruption in infrastructure services}

The construction sector is estimated globally to be worth some US\$3,200 billion per year and some US $\$ 250$ billion is spent annually on infrastructure in the developing world alone (Rodriguez, Waite, and Wolfe, 2005). However, worldwide, the construction sector is known for its association with corruption (Zarkada-Fraser \& Skitmore, 2000; DFID, 2002). Corruption in the construction industry covers new build contracts, refurbishment contracts, as well as maintenance contracts. Corruption in the sector includes all 
forms and can be found at all levels from high ranking officials diverting funds and international companies offering bribes for contracts down to the petty local operators who falsify meter readings or seek bribes for water connections. Transparency International's Global Corruption Report (Rodriguez, Waite \& Wolfe, 2005) highlights the devastating impact of corruption in construction (such as wasted tender expenses, tendering uncertainty, increased project costs, economic damage, blackmail, criminal prosecutions, fines, blacklisting, brand damage and reputational risk). Table 1 summarizes the key corruption vulnerabilities in the construction project cycle and infrastructure service delivery. This table outlines the key stakeholders involved and provides examples of the kinds of corruption that might be found at each stage in project delivery. The table is also helpful in thinking about measures to address the problem.

Corruption in the construction industry often results from a combination of:

- deregulating the infrastructure sector,

- the large flow of public money,

- the highly competitive nature of the tendering process,

- a lack of transparent selection criteria for projects,

- political interference and discretion in investment decisions, the cost of sector assets,

- the monopolistic nature of service delivery,

- tight margins,

- close relationships between contractors,

- subcontractors and project owners,

- the complexity of institutional roles and functions the asymmetry of information between user and provider, or cronyism in the industry (Stansbury, 2005; Rodriguez, Waite, and Wolfe, 2005,). PricewaterhouseCoopers' (2003)

Global Economic Crime Survey examined data from 184 construction companies in 44 countries around the world and found that corruption and bribery are currently a substantial threat, with one-third of those surveyed having experienced some form of economic crime. The subsidiary Calcestruzzi (an Italian cement firm) of the construction materials giant Italcementi closed its operations in Sicily "as a sign of a refusal to 
submit to, or to show any compliance with" the Mafia, which extorts money from practically all public works contractors. In addition, corruption represents a threat to those institutions and companies which are financing, guaranteeing or insuring construction projects. Whilst corruption might once have been viewed as a necessary requirement of doing business, it is increasingly seen instead as a form of misconduct. For example, Britain banned U.K.-based companies from making facilitation payments as part of the AntiTerrorism, Crime and Security Act 2001. Companies are increasingly establishing comprehensive anticorruption and bribery programs that include written policies, training, and auditing and internal controls.

Yet, PricewaterhouseCoopers (2003) found that corruption generates immense opportunities for payoffs with comparatively low risk of detection and punishment since instances of corruption often only come to light as the result of either a tip-off or accidental discovery. This is a key problem in the construction industry where corruption can be obscured by:

- The complexity of projects: projects may be designed to ensure higher overhead recovery and profit for the contractor whereas an alternative cheaper design would have been adequate.

- Large numbers of small-scale contractors: The number of small-scale local contractors engaged for construction and maintenance works can make monitoring time and resource intensive.

- Delays and cost overruns: sub-contractors may deliberately overstate the time and cost requirements (and falsifies time sheets) in order to achieve a higher price from the contractor.

- Concealment of the quality of work: defective materials could be used, materials that are cheaper and inferior specification or materials omitted such as structural steel (Stansbury, 2005; Stansbury, and Stansbury, 2007; Rodriguez, Waite, and Wolfe, 2005).

\section{Arrangements to combat corruption}

The discussion that follows highlights a range of initiatives that have targeted one or another type of aspect of the conceptual framework as a way of controlling corruption in the construction sector.

\section{Awareness-raising:}


Corruption: Greater transparency can make a significant contribution to reducing corruption and embezzlement. Promoting greater transparency around the actions of officials creates disincentives for them to engage in corrupt transactions and also raises citizens' awareness of the goods and services they should receive. A survey by the Chartered Institute of Building in the UK (2006) examines how common corruption is within the UK construction sector and what the perception of that corruption is within the sector. The authorities in the Netherlands have conducted two very large investigations into construction cartels and bid rigging. About 1,400 companies have been fined, and the penalties imposed are the equivalent of over $£ 200$ million.

Cultural norms: The media can do much to disseminate information about corruption in the construction sector informing both the public and policymakers and prompting investigations by official bodies. Transparency International Bangladesh (TIB, 2002) developed the 'News Scan Database', a database of corruption stories from newspaper archives. This tool is intended not only to measure the nature and extent of corruption in Bangladesh, but also to encourage the media to further investigate and report instances of corruption. Similarly, Transparency Thailand (TT) produced a series of radio shows (in Bangkok and rural areas of Thailand) dealing with the problems of corruption and the lack of transparency in government and business circles.

Ethics: Increasing the amount of information (such as public accounts, budgets, contracting arrangements and annual reports) available to the public can also reduce corruption in the sector by making it difficult for public officials to make decisions that misallocate resources, or tap into limited budgets. Transparency International Serbia developed the programme "Towards More Transparent Budgeting and Public Procurement in Municipalities in Serbia” in order to increase the efficiency and quality of municipal services, to improve communication and relations between the municipal administration and citizens and to establish a more efficient and transparent budgeting and public procurement system (Steets, 2001).

Accountability: In Abra, a province in the Northern Philippines, an NGO called Concerned Citizens of Abra for Good Government (CCAGG) trains community beneficiaries to conduct audits and monitor 
project implementation in order to reduce corruption in the construction of public works. CCAGG ensure that project specifications and proper equipment requirement are delivered satisfactorily. The presence of CCAGG monitors means that contractors are more likely to ensure that quality standards are met, hence ensuring project longevity. Public participation in budget formulation and spending reviews has been used to improve transparency in the financial administration of local authorities and contributes to a more equitable distribution of resources in Porto Alegre and Belo Horizonte, Brazil and Campo Elias, Venezuela. The experience in Brazil has shown that corruption has fallen and services are delivered more efficiently (Abers, 1998).

\section{Strengthened professional institutions:}

Corruption: Professional institutes have a key role in regulating the conduct of members on the basis of peer judgment. Currently, reported cases of professional misconduct in relation to corruption are rare.

Cultural norms: It is reported that the statutory registration of engineers in USA and Canada has improved professional ethics (Uff, 2003). An Anti-Corruption Forum in the UK (including The Institution of Civil Engineers, Association of Consulting Engineers, the British Consultants \& Construction Bureau, and TI-UK) is working on industry-led solutions to the problem of corruption in domestic and international infrastructure, construction and engineering.

Ethics: Efforts are currently being made to develop ethical standards for the construction sector as well as to ensure due diligence actions by construction companies to ensure that their business partners (e.g. agents, consortium and joint venture partners, and major sub-contractors) do not engage in corrupt activities. For example, Royal Academy of Engineering has developed a statement of four fundamental ethical principles which engineers should achieve in professional life (accuracy and veracity; honesty and integrity; respect life, law and public good; and responsible leadership). The Society of Construction Law's Ethics Group issued a statement on ethical issues and has provided guidance on the application of ethical principles. 
Accountability Sector-wide institutional reform strategies have included focusing on incentives, competition, and internal checks. Furthermore, at present not all trades in the construction industry have statutory registration or have their work regulated, indeed there is no single trade or professional association governs the industry.

\section{Prevention of corruption}

Corruption: Over the last decade, a number of theories and mechanisms have been developed and tested to prevent corruption in its various forms. These generally range from anti-corruption legislation (such as the UN Convention against Corruption and the OECD Convention Against Bribery of Foreign Public Officials in International Business Transactions, 1997), regulation, rules and procedures. However, these top-down approaches are rarely accompanied by effective enforcement and so have proven largely ineffective. More recently a number of mechanisms have been developed specifically for the construction sector, which are proving particularly effective.

Cultural norms: Individual, company or industry-specific codes of business conduct and professional standards are also key in corruption prevention. South Korea has adopted a Code of Conduct for Maintaining the Integrity of Public Officials. This code specifies the standards of conduct to be observed by both state and local public officials. It covers areas related to the prevention of conflict of interest, of using public office for private purposes, the obligation of neutrality and impartiality and regulates the acceptance of gifts. Anecdotal reports suggest that, since the code came into force, the number of duty-related offerings of gifts and hospitality have reduced substantially.

Corruption has generally been addressed in the public sector through civil service reform (including pay structures, promotions/appointments, recruitment, transfers, results-based management, terms and conditions, enforcement and sanctions, local stakeholder involvement, as well as civil service size, financial policies, leadership, competition, separation of policy, regulation and implementation). Yet it has been established that a focus on the public sector alone is not enough - increased salaries do not necessarily lower the incentive of officials to engage in corrupt practices - anti-corruption needs to include the private 
sector. In the UK, a body called the Local Government Task Force, works to help councils in their dealings with the construction industry. Recently, there have been a number of initiatives intended to build awareness and dialogue within the private sector on good business practices, transparency, and accountability for those training and working in the construction industry as well as to seek to improve integrity in private companies, national governments and construction companies respectively. Initiatives with multi-national companies and national companies operating in developing countries have mostly focused on achieving a greater level of integrity and professionalism among members through professional associations, codes of conduct, monitoring and benchmarking, and integrity pacts.

Ethics: The literature generally focuses largely on the "passive" corruption of government officials who accept bribes, rather than the "active" corruption of the corporations who pay them. The Wolfsberg Principles is an effort by private companies to fight corruption by practicing sound business and accepting to submit their social and ethical performance to public monitoring and scrutiny (corporate accountability). Business Principles for the Construction Sector have been developed to bolster transparent and ethical business conduct in the industry and have been endorsed by 19 leading international construction firms with annual revenues in excess of $\$ 70$ billion (the initiative has been facilitated by the World Economic Forum, Transparency International and the Basel Institute on Governance). An organization which adopts the Business Principles commits to adopt a "zero tolerance" policy on bribery and to develop a practical and effective program of internal systems and controls for implementing its anti-bribery policy. However, it is not possible to prescribe exhaustive guidelines to cover each and every single ethical concern that employees are likely to face in their work. In the private sector, a growing number of companies are designing programs that give employees a level of ethical understanding that allows them to make appropriate decisions.

Accountability: Transparency International advocates the use of an Integrity Pact to prevent corruption in the international private construction sector; this commits actors in a transaction (such as bidders and government agencies in a contractual relationship) to not offer or accept bribes in public contracting The Integrity Pact is a tool that has also been successful in cutting the costs of dozens of procurement 
procedures around the world, for example it has been used successfully in Pakistan, Nepal, Indonesia, and in Colombia by the local Transparency International National Chapters. Transparency International Argentina (Poder Ciudadano) has adapted the Integrity Pact to include public hearings whereby municipal authorities convene citizens, businesses, experts, and representatives of the opposition to express their objections and suggestions about the planned terms of the contracting. Poder Ciudadano first used these tools for monitoring the procurement process for waste collection service at the municipal level in the city of Morón. All bidders accepted the conditions imposed by the Integrity Pact without objection, and signed in September 2000. Poder Ciudadano monitored the Integrity Pact, the bid evaluation, the award decision process, and the implementation of the contract and ensured maximum coverage in the print and electronic media, at both local and national levels. The Integrity Pact gave the losing companies a concrete mechanism to monitor how the winning bidder addresses the terms of the contract. Most recently Integrity Pacts have been used in the EUR2 billion development of the Berlin-Brandenburg International Airport in Germany.

Increasing use is made of information technologies in the fight against corruption. For example, www.licitenet.com is an online database created to inform the public about the process of public procurement in Ecuador. It is a joint initiative between the private sector and civil society to create more transparency within public procurement, to allow the public to follow and monitor procurement of relevance to their community and to decrease the discretionary powers of public officials in this area. Eprocurement has been recognized internationally as an important instrument for checking corruption and misuse of power. An e-procurement system was introduced in the Republic of Korea in 1998 for purchasing goods and services and arranging contracts for construction projects. All procurement from purchase requests to electronic tendering, and payment is processed on line. Automation has simplified the bidding procedure, improved competition, avoided preferential treatment, and eliminated non-arbitrary behaviour.

\section{Enforcement and monitoring measures:}


Corruption: It was noted earlier that for anti-corruption approaches to prove effective it depends on effective enforcement. Tough sanctions are needed against companies caught bribing, including forfeiture of the contract and blacklisting from future bidding. For example, progress has been made in recognising the problem of corruption by both multilateral development banks and export credit agencies. The World Bank includes fraud and corruption provisions in its procurement and consultants guidelines; companies found to have violated the provisions are placed on a public blacklist that is used by the World Bank and some credit agencies when considering loans and contracts (World Bank, 2000). Nearly 70 firms have been permanently banned in this way from competing for World Bank contracts. Regional development banks have taken a similar approach. However, combating corruption requires political will, for example an investigation by the Serious Fraud Office stopped its investigation into BAE Systems' arms deals with Saudi Arabia, amid fears for its vast contract to sell Typhoon fighters.

Cultural norms: Citizens have been directly involved in fighting corruption by monitoring their infrastructure delivery. For example, community-based audits where corruption is suspected in the delivery of public works have been organised in slum areas of Delhi by an NGO called Parivartan using Right to Information Law (RTI) to access records of public works. The Right to Information (RTI) has been recognized the world over as an important instrument for checking corruption and misuse of power. The documents requested under the Right to Information Act include copies of work order registers, measurement books (including record entries and abstract entries), sketches, details of estimates and completion certificates and it is also possible to obtain a sample of any materials used in construction. After compiling this information Parivartan holds a series of street corner meetings to inform the people of the amount spent in their block on public works, the works purported to have been carried out under each contract, the amount spent on each of the works, as per government records. It is then established whether the works have been carried out and if it is of satisfactory quality. Public hearings (jansunwai) are then organized to discuss publicly the works audited. The public hearings enable residents, government officers and political representatives to give evidence regarding the stated expenditure and on the status and quality of works, to verify government records on expenditure and the status and quality of the works recorded as having been carried out. These hearings have exposed large scale corruption in public works. Social 
auditing of construction projects is particularly suitable in cases where projects do not need high technical skills (construction of culverts, bridges, roads, irrigation and water systems).

Ethics: Organizational ethics initiative include: codes of conduct, leadership training and resources, due diligence and financial disclosure, communications and training (e.g. British Standards Institution (BSI) anti-corruption training modules for the British construction industry), auditing and monitoring, enforcement and voluntary disclosure, It is not possible to prescribe exhaustive guidelines to cover each and every single ethical concern that employees are likely to face in their work. A common approach to determine the ethical standards of behaviour of its management and employees is to take into account legal requirements, a company's own ethical values, collective standards of practice, basic values and general community expectations.

Recently, effective enforcement of accountability arrangements has been seen to depend on community monitoring, especially where the police and judiciary are themselves corrupt - making sanctions impossible. This has also been acknowledged by The World Development Report, Making Services Work for the Poor (2004), which highlights the need to shorten and strengthen accountability relationships between policy makers / politicians, service providers, and citizens.

Accountability: Paul (1992) has demonstrated how organised public feedback in the form of report cards can be used to challenge service providers to be more efficient and responsive to consumers. Report cards were started by the Public Affairs Centre (PAC) - an NGO based in Bangalore. First used in 1993, report cards use citizen feedback to rate the performance of public services agencies, such as the electricity board, water board, telecommunications, and public banks amongst others. More recently, the Citizen’s Report Card has been conducted on The Nairobi Water and Sewerage Company (NWSC) by a consortium of civil society groups, on urban water, sanitation and solid waste services. The results of the report cards are shared with NGOs, citizen bodies, other public interest groups, citizens and service providers and widely publicized in the press. Public agencies are urged to respond to the report card by improving services. The data produced has been used to rate the performance of public service providers and to highlight aspects of 
their services that need improvements. The findings can empower citizens to interact with service providers in a more informed manner. The Report Card process can also be repeated over time and compared across services and cities, putting greater pressure on public officials to listen. The success of report cards depends on the capacity and interest of civil society to lobby for change and the ability and willingness of agencies to respond.

A number of global non-governmental anti-corruption organizations have a major role in curbing corruption in the sector; for example Transparency International has developed Minimum Standards for Public Contracting provides a global baseline for public contracting rules that meet minimum international standards; Transparent Agents and Contracting Entities vets, certifies, and trains intermediaries such as consultants, brokers, sponsors, agents; Publish What You Pay calls for business to release information about all payments made to governments to ensure the funds benefit the public rather than corrupt bureaucrats or politicians.

However, a critical aspect in the success of community monitoring and enforcement is the existence of an effective complaints redressal system as well as the institutionalization of mechanisms to strengthen civil society's role in monitoring the construction sector. These systems increase service users’ power, create a direct relationship of accountability (giving service providers incentives not to engage in corruption) and provide a means of enforcement and sanctions for corruption, non-compliance or poor performance.

\section{Reviewing the conceptual framework}

This paper introduced a conceptual framework, developed from the literature review, to draw conclusions about the effectiveness of combating corruption in the sector. This framework consists of four components: 'corruption', 'cultural norms', 'ethics', and 'accountability'. This section brings together the framework and the discussed examples above. The evidence presented in this paper suggests that successful initiatives to combat corruption through improved accountability have integrated both universal ethical principals as well as culture-bound attitudes and customs. For example: 
Corruption: A general definition of corruption is the misuse of power for private gain either at one's own instigation or in response to inducements.

Cultural norms: Corruption, particularly in developing countries, is often viewed as a cultural problem. However, the international experience described above suggests that corruption is no more acceptable or desirable in developing than developed countries. Although there are a number of generic approaches to combat corruption in the international construction sector, the case studies provided above also point to the importance of culturally relevant anti-corruption methods. The evidence suggests that combating corruption is not a purely technocratic issue, capable of being carried out in isolation from a country’s history, cultural tradition of politics or political culture. Indeed it is suggested that culture is crucial to combating corruption, since social change can only be sustainable if it can be internalised through the ways and values of people.

Ethics: Understanding corruption as an ethical problem is important for policy makers in the construction sector when developing models for improving accountability and reducing corruption. Codes of ethics and training around ethics issues have been developed by government and professional associations with the aim of ensuring that members' behaviour is corruption-free. Many companies require contractors, subcontractors and third party agents like suppliers to be contractually bound to a company’s corruption and bribery policies and respect the same codes of conduct as other employees, i.e. not engage in any form of collusive or unethical practices and to act ethically, fairly and honestly. Other mechanisms include business principles to combat bribery, conflict of interest laws and rules, and whistleblower protection. However there also need to be consequences of not complying with ethical requirements such as: termination of contracts, loss of future work, loss of reputation, investigation for corruption and matters being referred for criminal investigation.

Accountability: A number of accountability initiatives for the corruption sector have been developed and tested with success in both developed countries and developing countries. These initiatives are intended to 
make tender procedures, procurement and project implementation more transparent, and ensure that construction management and procurement staff operate with less discretion, and that their actions are overseen and sanctions enforced if necessary.

Suggestions for operationalising this framework are set out below in Table 2.

Table 2: Summary for operationalising the framework

\begin{tabular}{|c|c|c|c|c|}
\hline & Awareness raising & $\begin{array}{l}\text { Strengthening } \\
\text { professional institutions }\end{array}$ & $\begin{array}{l}\text { Prevention of } \\
\text { corruption }\end{array}$ & $\begin{array}{l}\text { Enforcement } \\
\text { and monitoring } \\
\text { measures }\end{array}$ \\
\hline Corruption & $\begin{array}{l}\text { Increased } \\
\text { transparency around } \\
\text { construction projects } \\
\text { of government } \\
\text { revenue and } \\
\text { expenditure flows }\end{array}$ & $\begin{array}{l}\text { Trade or professional } \\
\text { association take action on } \\
\text { corrupt practices }\end{array}$ & $\begin{array}{l}\text { Project owners } \\
\text { implement } \\
\text { Integrity } \\
\text { Pact during tender } \\
\text { and project } \\
\text { execution phases }\end{array}$ & $\begin{array}{l}\text { Companies caught } \\
\text { bribing are } \\
\text { blacklisted }\end{array}$ \\
\hline $\begin{array}{l}\text { Cultural } \\
\text { norms }\end{array}$ & $\begin{array}{l}\text { Understanding of } \\
\text { cultural differences } \\
\text { and their relevance to } \\
\text { corruption; and the } \\
\text { differences between } \\
\text { bribes, hospitability } \\
\text { and gifts }\end{array}$ & $\begin{array}{l}\text { The private sector } \\
\text { implements and enforces } \\
\text { corporate compliance } \\
\text { programmes relating to } \\
\text { domestic laws criminalizing } \\
\text { foreign bribery }\end{array}$ & $\begin{array}{l}\text { As well as } \\
\text { international good } \\
\text { practice attention } \\
\text { should be paid to } \\
\text { national } \\
\text { experience of anti- } \\
\text { corruption } \\
\text { mechanisms }\end{array}$ & $\begin{array}{l}\text { Programmes should } \\
\text { be tailored to each } \\
\text { country context }\end{array}$ \\
\hline Ethics & $\begin{array}{l}\text { Core ethical } \\
\text { standards and codes } \\
\text { of conduct should be } \\
\text { developed to guide } \\
\text { behaviour }\end{array}$ & $\begin{array}{l}\text { Trade or professional } \\
\text { associations enforce their } \\
\text { ethical policies and take } \\
\text { action on corrupt practices }\end{array}$ & $\begin{array}{l}\text { Training package } \\
\text { created to support } \\
\text { the application of } \\
\text { ethics/ promote } \\
\text { ethics with other } \\
\text { anti-corruption } \\
\text { measures }\end{array}$ & $\begin{array}{l}\text { Give employees a } \\
\text { level of ethical } \\
\text { understanding that } \\
\text { allows them to } \\
\text { make appropriate } \\
\text { decisions }\end{array}$ \\
\hline Accountability & $\begin{array}{l}\text { Build awareness and } \\
\text { dialogue within the } \\
\text { sector on good } \\
\text { business practices, } \\
\text { transparency, and } \\
\text { accountability for } \\
\text { those in the } \\
\text { construction industry }\end{array}$ & $\begin{array}{l}\text { Professionals in the } \\
\text { construction industry have } \\
\text { strong written policies, } \\
\text { training in codes of conduct } \\
\text { and ethics program } \\
\text { development and } \\
\text { implementation with strong } \\
\text { whistleblower policies to } \\
\text { enable them to deal with } \\
\text { petty bribery and corruption }\end{array}$ & $\begin{array}{l}\text { Ensure all groups } \\
\text { within a society } \\
\text { have a role to play } \\
\text { in promoting } \\
\text { ethics in the } \\
\text { sector. }\end{array}$ & $\begin{array}{l}\text { Monitoring by } \\
\text { independent } \\
\text { oversight agencies } \\
\text { and the private } \\
\text { sector }\end{array}$ \\
\hline
\end{tabular}

\section{Conclusion}

The challenges of corruption in the construction sector are significant: corrupt practices, such as bribery, embezzlement, kickbacks and fraud, can occur at every phase of a construction project. In recent years there has been a growing commitment to the anti-corruption agenda in the construction sector. This paper 
has outlined a conceptual framework including examples of corruption in the construction sector, the rationale for applying greater accountability, provided a comparative examination of international good practice in the construction sector and examples of the application of ethics to construction sector. The most promising strategies for operationalising this framework focus on (i) awareness raising (improving demand, improving voice and participation) (ii) strengthening professional institutions (iii) prevention of corruption and (iv) enforcement and monitoring measures. It is hoped that with improved accountability and reduced corruption, it will be possible to construct, operate and maintain adequate quality and quantity of infrastructure on a more sustainable basis and thereby improve construction practice. 
Reference:

1. Abers, R. (1998) 'Learning democratic practice: distributing government resources through popular participation in Porto Alegre, Brazil' pp.39-65 in Douglass, M., Friedmann, J. (ed.) Cities for Citizens. West Sussex: John Wiley and Sons

2. Andvig, C, J and Fjeldstad, O, H (2000), 'Research on Corruption: A Policy Orientated Survey’, Final Report (NORAD), December 2000.

3. ASCE [American Society for Civil Engineers] (September 30, 2004). Press Release: "Civil Engineers Call For Global Standards to Curb Trillion Dollar Worldwide Corruption.” http://asce.org/pressroom/news/display_press.cfm?uid=1711

4. Bo Dal. E. and Rossi M. A. (2004). "Corruption and Efficiency: Theory and Evidence from Electric Utilities.” Mimeo. University of California, Berkeley, and University of Oxford.

5. Cavill, S. and Sohail, M. (2005). "Improving public urban services through increased accountability." Journal of Professional Issues in Engineering Education and Practice, American Society of Civil Engineers. Vol 131 (4), 263-273.

6. Commission for Africa. (2005). Our Common Interest: Report of the Commission for Africa. http://www.commissionforafrica.org/english/report/introduction.html

7. Davis, J. (2004). "Corruption in public service delivery: experience from South Asia's water and sanitation sector." World Development, 32 (1), 53-71.

8. Estache, A. and Kouassi, E. (2002). Sector organization, governance, and inefficiency of African water utilities. World Bank Policy Research Working Paper No. 2890. The World Bank Institute, Washington.

9. Schedler, A. (1999) 'Conceptualising Accountability', pp. 14-17 in Schedler, A., Diamond, GO., Plattiner, MF. (eds.) (1999) The Self Restraining State: Power and Accountability in New Democracies. London: Lynne Reinner.

10. Shadrach, B. and Ekeayanwu. L. (2003). "Improving transparency, quality and effectiveness of pro-poor public services using the ICTs: An attempt by Transparency International". Paper presented at the $11^{\text {th }}$ International Anti-Corruption Conference Seoul, 25-28 May 2003.

11. Stansbury, N. (2005). "Exposing the foundations of corruption in construction.” In Global Corruption Report (2005) Special Focus: Corruption in Construction and Post Conflict Reconstruction. Pluto Press, London.

12. Stansbury, C and Stansbury, N (2007) Anti-Corruption Training Manual (Infrastructure, Construction and Engineering Sectors) International Version Transparency International UK

13. Steets, J. (2001). Serbia: Budgeting and Public Procurement. Transparency International

14. Uff, J. (2003). Duties on the legal fringe: ethics in construction law. The Michael Brown Foundation $4^{\text {th }}$ public lecture, Kings College London, $19^{\text {th }}$ June 2003.

15. Zarkada-Fraser, A. and Skitmore, M. (2000) Decisions with moral content: collusion Construction Management and Economics (2000) 18, 101- 111

16. Rodriguez, D., Waite, G. and Wolfe, T. (eds.) (2005). The Global Corruption Report 2005. Pluto Press, London. http://www.globalcorruptionreport.org

17. Rooke, P. and Wiehen, M.H. (1999). Hong Kong: The Airport Core Programme and the Absence of Corruption. Report by a Mission of Transparency International, December 1999.

18. PricewaterhouseCoopers' (2003). Global Economic Crime Survey. PricewaterhouseCoopers, London.

19. Williams, R. (1987). Political Corruption in Africa. Aldershot England, Hampshire

20. Klitgaard, R. (1988). Controlling Corruption. University of California Press, Berkeley. 
21. Robinson, M. (1998). Corruption and Development: An Introduction. pp. 1-14. in Robinson, M. (1998). Corruption and Development. Frank Cass, London.

22. Rose-Ackerman, S. (2004). Establishing the Rule of Law. pp. 182-221 in Rotberg, R (ed) When States Fail: Causes and Consequences. Princeton University Press, Princeton NJ.

23. Persson, T., Tabellini, G. and Trebbi, F. (2003). "Electoral rules and corruption.” Journal of the European Economic Association.

24. Alesina, A., and Weder, B. (2002). "Do corrupt governments receive less foreign aid?” American Economic Review 92, 1126-1137.

25. Deininger, K. (2003). "Does cost of schooling affect enrolment by the poor? Universal primary education in Uganda." Economics of Education Review, 22, 291-305.

26. Korea Centre for City and Environment Research (1999) The IMF Crisis and City: The Case of South Korea. Seoul: Korea Centre for City and Environment Research

27. DFID [Department for International Development] (2002) "Making Connections: Infrastructure for Poverty Reduction." www.dfid.gov.uk/pubs/files/making_connections.pdf

28. Transparency International Bangladesh News Scan Analysis 2002 available on website, http://www.ti-bangladesh.org

29. The World Bank, Preventing Fraud and Corruption in World Bank Projects: A Guide for Staff (World Bank: 2000)

30. Paul, S. (1992). “Accountability in Public Services: Exit, Voice and Control.” World Development, 20(7), 1047 - 1060.

31. The Chartered Institute of Building Survey (2006) Corruption in the UK Construction Industry 
Table 1: Examples of corruption in the different stages of infrastructure delivery

\begin{tabular}{|c|c|c|}
\hline $\begin{array}{l}\text { Stage of service } \\
\text { delivery }\end{array}$ & Key stakeholders & Examples \\
\hline Project selection & $\begin{array}{ll} & \text { public clients } \\
\text { - } & \text { private clients }\end{array}$ & $\begin{array}{l}\text { - Corruption can negatively affect the selection of projects. For example, } \\
\text { corruption can divert resources away from social sectors and toward major } \\
\text { infrastructure projects. } \\
\text { Corruption may also encourage the selection of uneconomical projects } \\
\text { because of opportunities for financial kickbacks and political patronage. }\end{array}$ \\
\hline Planning stages & $\begin{array}{ll} & \text { public clients } \\
\text { - } & \text { private clients } \\
\text { - } & \text { financiers } \\
\text { - } & \text { legal advisors }\end{array}$ & $\begin{array}{l}\text { Project used as vote winners/opportunities for personal gain not on basis of } \\
\text { priority/availability of financial resources. } \\
\text { Planning in favour of high value infrastructure (white elephant projects) and } \\
\text { against the interest of the poor. } \\
\text { - } \quad \text { Project requirements may be overstated or tailored to fit one specific bidder. }\end{array}$ \\
\hline Inspection stages & $\begin{array}{ll}- & \text { regulatory } \\
& \text { authorities }\end{array}$ & $\begin{array}{l}\text { - Weak oversight and supervision mechanisms have been created that would } \\
\text { prevent detection of fraud and corruption. } \\
\text { Kick-backs can be given to persuade inspectors to turn a blind eye to slow } \\
\text { implementation of projects, unfulfilled contract requirements, and other } \\
\text { instances of malpractice. }\end{array}$ \\
\hline Design & $\begin{array}{ll}- & \text { design } \\
& \text { consultants } \\
\text { - } & \text { public clients } \\
\text { - } & \text { private clients }\end{array}$ & $\begin{array}{l}\text { - Corrupt selection of consultants for feasibility studies, preparation of } \\
\text { specifications/bid documents. } \\
\text { Over designed and overpriced projects to increase potential corrupt earnings } \\
\text { during implementation. } \\
\text { - Bribe for favourable environmental impact assessment/planning } \\
\text { proposal/approval. } \\
\text { Project design has been manipulated to benefit particular suppliers, } \\
\text { consultants, contractors, and other private parties. } \\
\text { - The timing of the project has been altered to suit vested interests. }\end{array}$ \\
\hline $\begin{array}{l}\text { Bid and contract } \\
\text { signing stage }\end{array}$ & $\begin{array}{ll}- & \text { contractors } \\
\text { - } & \text { subcontractors } \\
\text { - } & \text { suppliers }\end{array}$ &  \\
\hline Construction & $\begin{array}{ll}\text { - } & \text { contractors } \\
\text { - } & \text { subcontractors } \\
\text { - } & \text { suppliers }\end{array}$ & $\begin{array}{l}\text { - } \quad \text { Changing subcontract party after receiving bribes. } \\
\text { - } \quad \text { Cutting corners, ignoring rules, by passing procedures } \\
\text { - } \quad \text { Payment for equipment, materials or services which were not supplied. } \\
\text { The provision of equipment or goods of lower then specified quality (typical } \\
\text { - } \quad \text { Conamples include lesser cement or steel reinforcements). } \\
\text { - } \quad \text { Bribe the relevant official to certify that the work was done according to } \\
\text { - } \quad \text { Non-implementation. } \\
\text { - } \quad \text { Unjustified complaints from contractors as a way to obtain unjustified } \\
\text { contract price increases. } \\
\text { Duplication of payments, alteration of invoices, lack of supporting records, } \\
\text { ineligible payments, over billing, misuse of funds (i.e. for purposes other } \\
\text { than those aligned to project needs), misappropriation of discounts from } \\
\text { - } \quad \text { Unppliers/contractors, unauthorised payments etc. } \\
\text { - Theft of materials, equipment or services. } \\
\text { Entrepreneurs and brokers that exist as 'fixers' facilitating relations between } \\
\text { government and business players and negotiate the various administrative } \\
\text { and legal steps. }\end{array}$ \\
\hline Service delivery & public & Ghost/absent workers. \\
\hline
\end{tabular}




\begin{tabular}{|c|c|c|}
\hline & $\begin{array}{ll} & \text { private clients } \\
\text { - } & \text { contractors } \\
& \text { subcontractors }\end{array}$ & $\begin{array}{ll} & \text { Siphoning off supplies to market. } \\
\text { - } & \text { Favouritism in hiring/promotions } \\
\text { - } & \text { Use of contacts/money to get better/faster service or to prevent delays. } \\
\text { - } & \text { Elite capture of infrastructure services. }\end{array}$ \\
\hline $\begin{array}{l}\text { Maintenance and } \\
\text { management } \\
\text { stages }\end{array}$ & $\begin{array}{ll}\text { - } & \text { public clients } \\
\text { - } & \text { private clients } \\
\text { - } & \text { contractors } \\
\text { - } & \text { subcontractors } \\
\text { - } & \text { suppliers }\end{array}$ & $\begin{array}{l}\text { - } \quad \text { Corruption in procurement of equipment and spare parts. } \\
\text { - Withholding needed approval/signatures of gifts/favours. } \\
\text { - } \quad \text { Corruption increases costs meaning lack of resources for O\&M. } \\
\text { Bribes to win O\&M contracts/ personnel appointments. } \\
\text { Lower standard of construction creates need for expensive repair and } \\
\text { maintenance. }\end{array}$ \\
\hline
\end{tabular}

